
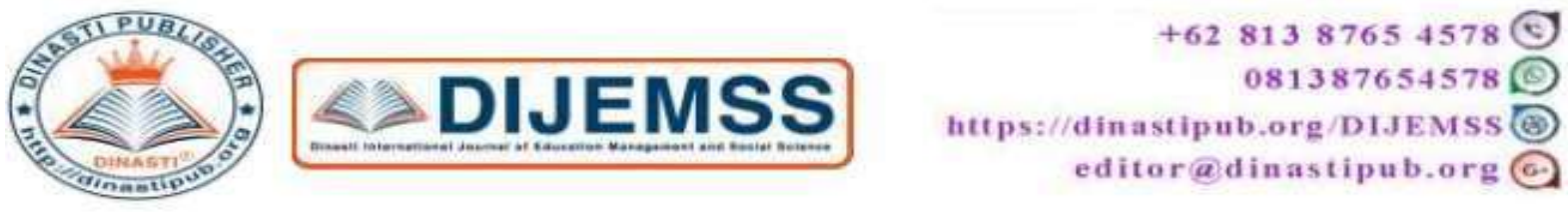

\title{
ANALYSIS OF SATISFACTION OF NATIONAL HEALTH INSURANCE JKN \\ PARTICIPANTS THROUGH QUALITY OF MOBILE SERVICES AND \\ CONFIDENCE MEDIATED BY DECISION TO CHOOSE MOBILE JKN SERVICE ON BPJS KESEHATAN OF PEKANBARU
}

Fitria Ichsani ${ }^{1)}$ Sri Hartono ${ }^{2)}$

${ }^{1)}$ Magister of Management, Mercu Buana University, Jakarta, Indonesia

${ }^{2)}$ Lecturer of Postgraduate, Mercu Buana University, Jakarta, Indonesia

\begin{tabular}{|c|c|}
\hline $\begin{array}{l}\text { ARTICLE INFORMATION } \\
\text { Received: } 30 \text { January } 2020 \\
\text { Revised: } 5 \text { February } 2020 \\
\text { Issued: } 10 \text { February } 2020 \\
\text { Corresponding author: } \\
\text { Fitria Ichsani } \\
\text { E-mail: } \\
\text { ichsanifitria@ gmail.com }\end{array}$ & $\begin{array}{l}\text { Abstract: The purpose of this study is to find out } \\
\text { how Analysis of Satisfaction of National Health } \\
\text { Insurance JKN Participants through Quality of } \\
\text { Mobile Services and Confidence Mediated by } \\
\text { Decision to Choose Mobile JKN Service on BPJS } \\
\text { Kesehatan of Pekanbaru, by measuring indicators } \\
\text { that influence variables service quality, trust, } \\
\text { decision and satisfaction. This research applies a } \\
\text { descriptive research design using survey methods. } \\
\text { Sampling uses certain criteria where the respondent } \\
\text { is a health insurance participant as a sampling } \\
\text { technique. This study was tested using the structural } \\
\text { equation modeling (Lisrel) approach to test the } \\
\text { significance of the significance of the overall model } \\
\text { and predetermined pathway. The findings show that } \\
\text { mobile service quality variables have a positive and } \\
\text { significant effect on decisions, trust variables have a } \\
\text { positive and significant effect on decisions, decision } \\
\text { variables have a positive and significant effect on } \\
\text { participant satisfaction, mobile service quality } \\
\text { variables have a positive and significant effect on } \\
\text { satisfaction and trust variables have a positive and } \\
\text { significant effect on participant satisfaction. } \\
\text { Keywords: Satisfaction, Trust, Decision, Quality of } \\
\text { Service, }\end{array}$ \\
\hline
\end{tabular}

\section{INTRODUCTION}

BPJS Kesehatan (Social Security Administrative Body for Health) is a State-owned Enterprise specifically tasked by the government to provide health insurance for all Indonesians.

BPJS Kesehatan must be able to improve the quality of their services because good quality of services could play a significant role in improving the image of BPJS Kesehatan and satisfaction of the participants. Similarly, in recent years, the number of participnts of BPJS Kesehatan of Pekanbaru keeps increasing. 
Table 1.

Number Of Jkn Participants

\begin{tabular}{lll}
\hline Year & Participants & Development (\%) \\
\hline 2014 & 1.467 .699 & 0,00 \\
2015 & 1.523 .332 & 3,79 \\
2016 & 1.647 .424 & 8,15 \\
2017 & 1.788 .001 & 8,53 \\
2018 & 1.968 .190 & 10,08 \\
\hline
\end{tabular}

Table 1 shows that the number of JKN participants keeps increasing every year. Considering the massive public interest, BPJS Kesehatan of Pekanbaru should be able to improve the quality of the existing services to provide satisfaction for JKN participants. However, the trend of satisfaction of JKN participants based on Participant satisfaction index in recent years lowers, as shown in the following table.

Table 2.

Value Of Public Service Satisfaction Index In Pekanbaru

\begin{tabular}{|r|r|r|r|}
\hline \multirow{2}{*}{ Indeks Kepuasan Peserta } & 2016 & 2017 & 2018 \\
\cline { 2 - 4 } & 87,2 & 82,6 & 74,9 \\
\hline
\end{tabular}

Table 2 shows declining satisfaction index of JKN participants in the last three years. Declining satisfaction of JKN participants is due to increasing number of JKN participants in the last five years, as shown in Table 1 above, due to suboptimal services provided by the Pekanbaru Branch Office of BPJS Kesehatan.

BPJS Kesehatan nationally provides solution for this problem by launching mobile JKN. However, based on data collected from the field, as of today very few JKN participants of BPJS Kesehatan of Pekanbaru have activated mobile JKN [8]. This is shown in the following figure:


Fig. I. Number Of JKN Participants Who Have Activated Mobile JKN

Figure 1 shows that the number of JKN participants who have activated mobile JKN is 56,168. Compared with the number of registered participants in 2018 in Table 1, the number was very small, only 2.85 percent has activated it while 97.15 percent hasn't activated it. The activation trend keeps declining in recent years.

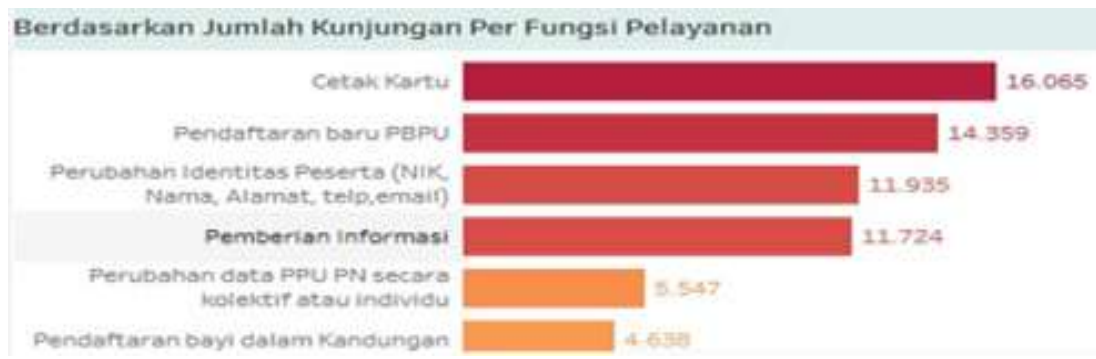

Fig. 2. Number Of Visits Per Service Function 
Below is the number of visits per service function which should be able to be performed via mobile JKN. Based on the number of visits per service function in Figure 2, all service functions are available on mobile JKN, but as of today mobile services haven't been used optimally by JKN participants and are still performed conventionally face-to-face in BPJS Kesehatan office of Pekanbaru.

Table 3.

Reason of jkn participants

\begin{tabular}{llll}
\hline No & \multicolumn{1}{c}{ Reason } & Amount & \multicolumn{1}{c}{ Percentage } \\
\hline 1 & $\begin{array}{l}\text { Lack of socialization about the use } \\
\text { of JKN Mobile }\end{array}$ & 5 & $16.67 \%$ \\
2 & $\begin{array}{l}\text { There is a sense of satisfaction } \\
\text { with getting direct service }\end{array}$ & 9 & $30 \%$ \\
3 & Do not have a device & 3 & $10 \%$ \\
4 & Don't understand using technology & 2 & $6.67 \%$ \\
5 & Lazy to learn to use. & 1 & $3.33 \%$ \\
6 & Less confident & 2 & $6.67 \%$ \\
7 & Fear of trying new things & 1 & $3.33 \%$ \\
8 & You can use this service directly & 5 & $16.67 \%$ \\
9 & Too difficult to use JKN Mobile & 2 & $6.67 \%$ \\
\hline Jumlah & 30 & $100 \%$ \\
\hline
\end{tabular}

Table 3 shows that 30 percent of JKN participants state that they still use services conventionally due to satisfaction when receiving direct services compared with using mobile JKN. 6.67 percent mention lack of socialization by BPJS Kesehatan of Pekanbaru to inform JKN participants, distrust, and difficulty in using mobile JKN, and other reasons as shown in Table 3.

Based on the phenomenon above and lack of study on improving the satisfaction of JKN participants through quality of mobile services and confidence mediated by decision to choose mobile JKN, it's interesting to turn this theme into an empirical study. Therefore, the present research studied the main problem, which is "Analysis of Satisfaction of National Health Insurance JKN Participants through Quality of Mobile Services and Confidence Mediated by Decision to Choose Mobile JKN Service A Study on BPJS Kesehatan of Pekanbaru".

\section{LITERATURE REVIEW}

Quality of Mobile Service, service quality is the expected level of excellence and control of the level of excellence is to meet customer desires.

Trust, consumer confidence is a company's willingness to rely on business partner. It depends on a number of interpersonal and inter-organizational factors, e.g. perceived company competency, integrity, honesty, and virtue. Confidence is belief that one will find what they want in exchange partner.

Decision Buying decision is a part of consumer behaviors, which is a study on how individual, group, and organization choose, buy, use, and how goods, services, idea or experience to satisfy their needs and desires.

Consumer satisfaction is a level where estimated product performance is consistent with buyer's expectation. Consumer satisfaction is one's happiness or disappointment which occurs after comparing the performance or outcome of a product with the performance or outcome expected before consuming or using the product. 
Framework is narration (description) or statement (proposition) on identified or formulated conceptual problem solving frame. Below is the framework of the present study:

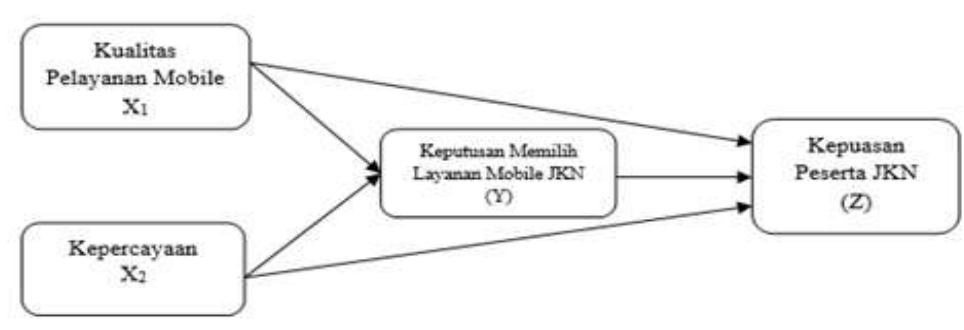

Fig. 3. Framework

\section{RESEARCH METHODS}

The present study was a causal relation using descriptive research method with quantitative approach. The research type was survey research. The research population all participants of JKN and BPJS Kesehatan of Pekanbaru who have used mobile JKN services. The research sampling used non-probability sampling with purposive sampling. The number of samples refer to the criteria proposed by Hair et.al [3] using Maximum Likelihood Estimation (MLE). Good number of samples according to MLE is 100-200 samples.

The data collection method in the present study was questionnaire using likert scale with five research scores administered to 140 respondents who met the sample criteria. The questionnaire was distributed online via google form. In the present study, the variables were categorized into: (1) Independent variables i.e.; $\left(\mathrm{X}_{1}\right)$ Service Quality and $\left(\mathrm{X}_{2}\right)$ Confidence (2) and Dependent variables i.e.; $\left(\mathrm{Y}_{1}\right)$ Decision to Choose and $\left(\mathrm{Y}_{2}\right)$ Participant Satisfaction.

The data analysis of the present study used LISREL 8.80 for processing primary data

\section{FINDINGS AND DISCUSSION}

Validity test shows how far an instrument can measure a variable to be measured. The basis for deciding whether a statement is valid or not is below: (1) if $r$ is positive and $r \geq 0.50$, then the statement item is valid, while (2) if $r$ is positive and $r<0.50$, then the statement item isn't valid. Based on Figure 3, all statement items are valid because all $r$ values of the statements are $\geq 0.50$.



Fig. 4. Standardized Loading Factor (SLF) 
Reliability test aims to determine the consistency of an instrument. The basis for deciding whether a research variable is reliable or not is as follows: (1) if Construct Reliability $\geq 0.70$ or Variance Extract $\geq 0.50$, then the research variable is reliable, while (2) if Construct Reliability $<0.70$ or Variance Extract $<0.50$, then the research variable isn't reliable. In the present study, all variables have construct reliability $\geq 0.70$ and Variance Extract $\geq 0.50$, so all research variables are reliable.

Table 4.

Goodness of fit index

\begin{tabular}{|c|c|c|c|c|}
\hline \multirow{3}{*}{$\begin{array}{l}\begin{array}{l}\text { Ukuran Goodnes Of } \\
\text { Fit }\end{array} \\
\text { Normed Chi-Square } \\
(\chi 2 / d f)\end{array}$} & \multicolumn{2}{|c|}{ Ukuran Kecocokan } & \multirow{2}{*}{\multicolumn{2}{|c|}{ Hasil Pengukuran }} \\
\hline & \multirow{2}{*}{$\begin{array}{l}\text { Good Fit } \\
<2.0\end{array}$} & \multirow[t]{2}{*}{ Marginal Fit } & & \\
\hline & & & 1.081 & Fit \\
\hline $\mathrm{P}$ Value & $\begin{array}{l}0.05<\mathrm{p}< \\
1.00\end{array}$ & $0.01<\mathrm{p}<0.05$ & 0.15 & Fit \\
\hline $\begin{array}{l}\text { Root Mean Square } \\
\text { Error (RMSEA) }\end{array}$ & $<0.08$ & & 0.023 & Fit \\
\hline $\begin{array}{l}\text { Goodness of Fit Index } \\
\text { (GFI) }\end{array}$ & $\geq 0.90$ & $0.80-<0.90$ & 0.85 & Marginal Fit \\
\hline $\begin{array}{l}\text { Adjusted Goodness of } \\
\text { Fit Index (AGFI) }\end{array}$ & $\geq 0.90$ & $0.70<0.90$ & 0.82 & Marginal Fit \\
\hline Normal Fit Index (NFI) & $\geq 0.90$ & $0.80-<0.90$ & 0.97 & Fit \\
\hline $\begin{array}{l}\text { Non-Normed Fit Index } \\
\text { (NNFI) }\end{array}$ & $\geq 0.90$ & $0.80-<0.90$ & 1.00 & Fit \\
\hline $\begin{array}{l}\text { Comparative Fit Index } \\
\text { (CFI) }\end{array}$ & $\geq 0.90$ & $0.80-<0.90$ & 1.00 & Fit \\
\hline $\begin{array}{l}\text { Increamental Fit Index } \\
\text { (IFI) }\end{array}$ & $\geq 0.90$ & $0.80-<0.90$ & 1.00 & Fit \\
\hline Relative Fit Index (RFI) & $\geq 0.90$ & $0.80-<0.90$ & 0.97 & Fit \\
\hline
\end{tabular}

Table 4 shows that model fitness value is good, i.e. good fit and marginal fit, meaning overall the fitness value of the research model shows good fit.

To test research hypothesis, the significance value $(\alpha)$ is 0.005 or $5 \%$ with $t$ value of $\geq$ 1.96.

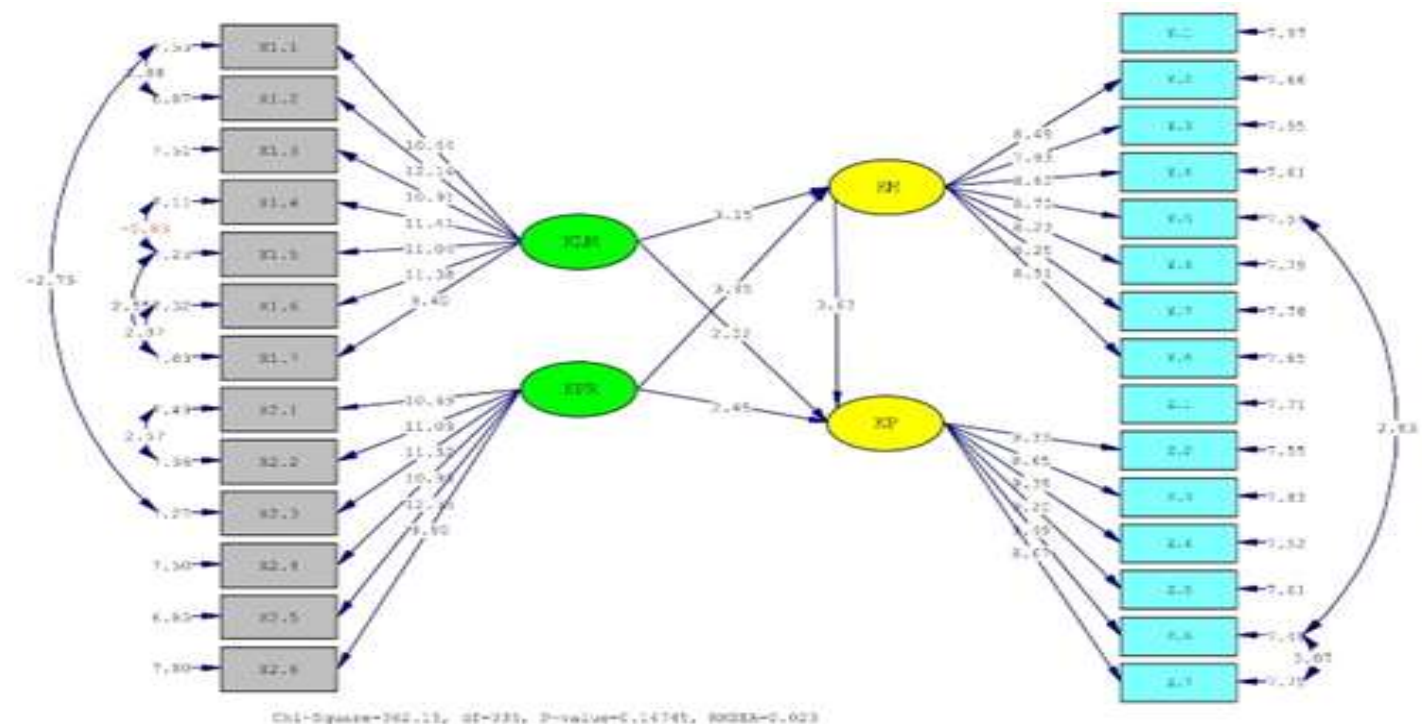

Fig. 5. T-Value

Table 5. 


\begin{tabular}{|c|c|c|c|}
\hline \multicolumn{4}{|c|}{ Research Hyphotesis Result } \\
\hline Hypothesis & Structural Path & T-Values & Conclusion \\
\hline $\mathrm{H} 1$ & $\begin{array}{l}\text { Mobile Service } \\
\text { Quality-> Decision }\end{array}$ & 3.15 & $\begin{array}{l}\text { positive and } \\
\text { significant effect }\end{array}$ \\
\hline $\mathrm{H} 2$ & Trust -> Decision & 3.95 & $\begin{array}{l}\text { positive and } \\
\text { significant effect }\end{array}$ \\
\hline $\mathrm{H} 3$ & $\begin{array}{l}\text { Decision -> } \\
\text { Participant } \\
\text { Satisfaction }\end{array}$ & 3.63 & $\begin{array}{l}\text { positive and } \\
\text { significant effect }\end{array}$ \\
\hline $\mathrm{H} 4$ & $\begin{array}{l}\text { Mobile Service } \\
\text { Quality-> } \\
\text { Participant } \\
\text { Satisfaction }\end{array}$ & 2.02 & $\begin{array}{l}\text { positive and } \\
\text { significant effect }\end{array}$ \\
\hline H5 & $\begin{array}{l}\text { Trust -> Participant } \\
\text { Satisfaction }\end{array}$ & 2.49 & $\begin{array}{l}\text { positive and } \\
\text { significant effect }\end{array}$ \\
\hline
\end{tabular}

The research hypothesis $\left(\mathrm{H}_{1}\right)$ states that Mobile Service Quality has direct positive and significant effect on Decision to Choose. This was shown by t-value which is 3.15 bigger than 1.96. In other words, if JKN continued to improve service quality in terms of speed, ease, security, confidentiality, and accuracy of offline and online data, Decision to Choose would be affected. The research study also confirmed the research result of Tijjang, B., Kamase, J., Labbase, I., \& Plyriadi, A., (2017:82). The research result states that optimal service quality has significant effect in customer's decision to choose an insurance service. Similarly, the study by Saling., Modding, Basri., Semmaila, Baharuddin., \& Gani, Achmad (2016:76) states that service quality has positive and significant effect on buying decision.

The research hypothesis $\left(\mathrm{H}_{2}\right)$ states that Confidence has direct positive and significant effect on Decision to Choose. This was shown by t-value which is 3.95 bigger than 1.96. In other words, if JKN continued to improve participants' Confidence in terms of confidentiality of information, privacy, quality of information and ease in searching participants' needs in JKN mobile, Decision to Choose would be affected. The research result also confirmed the research result of Kumar, S. Pavan and Saha, Shilpi (2017:1) that confidence has positive and significant effect on decision making. It means higher consumer confidence, increases consumer's decision making on a service or product.

The research hypothesis $\left(\mathrm{H}_{3}\right)$ states that Mobile Service Quality has direct positive and significant effect on Participant Satisfaction. This was shown by t-value which is 2.02 bigger than 1.96. In other words, if JKN kept improving Mobile Service Quality, Participant Satisfaction would be affected. The research result also confirmed the research result of Chu, Po-Young; Lee, Gin-Yuan; Chao, Yu (2012:1271) that company which wants to grow should focus on service quality to improve customer satisfaction, because improved service quality will increase customer satisfaction.

The research hypothesis $\left(\mathrm{H}_{4}\right)$ states that Confidence has direct positive and significant effect on Participant Satisfaction. This was shown by t-value which is 2.49 bigger than 1.96. In other words, if Confidence improved, Participant Satisfaction would be affected. The research result also confirmed the research result of Putri, Y.A., Wahab, W., \& Shihab, M.S (2018:369), Mahaputra, M. Rizky (2017:737), and Gwo, Guang Lee \& Hsiu, Fen Lin (2005:161) that confidence positively and significantly affected customer satisfaction.

The research hypothesis $\left(\mathrm{H}_{5}\right)$ states that Decision to Choose has direct positive and significant effect on Participant Satisfaction. This was shown by t-value which is 3.63 bigger 
than 1.96. In other words, if Decision to Choose improved, it would affect Participant Satisfaction. The research result also confirmed the research result of Saling., Modding, Basri., Semmaila, Baharuddin., \& Gani, Achmad (2016:76) that buying decision has positive and significant effect on customer satisfaction.

\section{CONCLUSION AND SUGGESTION}

Based on data analysis and discussion in the previous chapter, the following research conclusions are drawn: (a) Quality of mobile JKN service has positive and significant effect on decision to choose mobile JKN service. (b) Confidence has positive and significant effect on decision to choose mobile JKN service. (c) Quality of mobile JKN service has positive and significant effect on mobile JKN participant satisfaction. (d) Confidence has positive and significant effect on mobile JKN participant satisfaction. (e) Decision to choose mobile JKN service has positive and significant effect on mobile JKN participant satisfaction

By analyzing the research result, some suggestions which could be considerations and inputs for National Health Insurance (JKN) and future researchers are: (1) Suggestion for the company BPJS Kesehatan is expected to improve the quality of mobile JKN service as in the present study, it was indicated that speed and ease have the lowest loading factor values. This shows that to improve service quality, the company should also note participant's trouble in accessing mobile JKN service, which is considered slow and difficult to access. Improving the performance of features on Mobile JKN application, e.g. ease of health facility transfer, participant data editing, health screening, ease of payment, history of service, complaint box, etc., will increase participants' decision to use mobile JKN service. (2) BPJS Kesehatan is expected to be able to enhance the confidence of mobile JKN participants as the present study found that consistency with the statement "I feel the data and information consistency through conventional means and Mobile JKN is good" has the lowest loading factor value. It shows that to improve participants' confidence, the company should note the accuracy of data and information provided by conventional and mobile JKN services to JKN participants, so that the participants don't hesitate in deciding to use mobile JKN services. (3) Future studies should add other variables which affect buying decision, e.g. price, word of mouth, trust, security, brand and promotion.

\section{REFERENCE}

Chu, P.-Y., Lee, G.-Y., \& Chao, Y. (2012). Service quality, customer satisfaction, customer trust, and loyalty in an e-banking context. Social Behavior and Personality: An international journal, 40, 1271-1284.

Gwo-Guang Lee ve Hsiu-Fen Lin. "Customer perceptions of e-service quality in online shopping”, International Journal of Retail \& Distribution Management. 33:2, 2005, 161-176.

Hair, Joseph F., William C. Black, Barry J. Babin dan Rolph E. Anderson. (2010). Multivariate Data Analysis, 7th ed. Pearson Prentice Hall. New Jersey.

Kotler, P. (2016). Manajamen Pemasaran, Jilid 1 dan 2. Jakarta: PT. Indeks Kelompok Gramedia.

Kumar, S. Pavan and Saha, Shilpi. (2017). Influence of Trust and Participation in Decision Making on Employee Attitudes in Indian Public Sector Undertakings. SAGE Open. 
Mahaputra, M. Rizky. (2017). The Influence of Trust and Customer Value to Customer Satisfaction on Bank BRI Branch Soetomo Jambi. Saudi Journal of Business and Management Studies Vol-2, Iss-8.

Putri, Y.A., Wahab, W., \& Shihab, M.S. (2018). The effect of service quality and brand trust on loyalty and the intervening role of customer satisfaction in transportation service. International Journal of Scientific and Research Publications, Volume 8, Issue 7. ISSN 2250-3153.

Peserta Program JKN. 224.149.019 (12 Maret, 2019) Diterima oleh: https://www.bpjskesehatan.go.id/bpjs/pages/detail/2014/16

Tijjang, B., Kamase, J., Labbase, I., \& Plyriadi, A. (2017). The Relevance of Marketing Mix and Service Quality on Students' Decision-Making Factors Regarding Higher Education and Satisfaction. IRA-International Journal of Management \& Social Sciences, ISSN 2455-2267; Vol.08, Issue 01.

Tjiptono, F. (2016). Manajemen Jasa. Yogyakarta : Andi Offset. 